\title{
Analgesia methods during labour and delivery
}

Samuel C. Hughes MD

Childbirth is a highly variable experience with regard to pain and the need for analgesia. While a multiparous patient, for example, may have a fairly rapid and benign vaginal delivery with little need for analgesia, other parturients have real need for pain relief or even solid anaesthesia. The anaesthetist must be knowledgeable about the pain pathways involved, the specific obstetric requirements, the patient's desires, and a variety of analgesic choices. The obstetric anaesthetist is in an unique position when compared to the routine operating room in that much of what is requested is "elective." Another important consideration is the need to look ahead and be prepared for rapidly changing requirements and expectations. The routine labour epidural may suddenly be required to provide anaesthesia for an emergency Caesarean section. This aspect of analgesia-anaesthesia for the parturient is extremely challenging as well as being very rewarding if the anaesthetist is well informed and prepared.

\section{Pain pathways}

In a lecture entitled "The myth of painless childbirth" Melzack' noted that a primiparous patient with no preparation for childbirth experienced pain similar to that of amputation of a digit and greater than cancer pain (Figure 1). Preparation for childbirth may decrease pain considerably by decreasing fear and anxiety and by preparing the patient to participate in the delivery. However, it is important for those teaching the various childbirth preparation courses, as well as participants, to remember that there is pain.

The pain of labour and delivery arises primarily from nociceptors in uterine and perineal structures. The pain is transmitted through sympathetic nerve fibres to thoracic spinal segments $T_{10-12}$ and lumbar segments $L_{1}$. As labour progresses, the focus becomes the sacral segments so that during the second stage of labour, $\mathrm{S}_{2-3-4}$ is the area of chief concern for pain management (Figure 2). If abdominal surgery is required, obviously a level to $T_{4}$ or slightly greater is required. Understanding these pathways gives the practitioner several choices for pain relief.

\section{Psychologic and alternative techniques}

Alternative approaches have been tried by many patients and may be appropriate with the well-motivated, well- informed, and well-prepared patient. ${ }^{2}$ Hypnosis has been used successfully but the patient must be susceptible and well prepared. The preparation includes multiple conditioning sessions with the therapist. The side-effects, however, have included acute anxiety and frank psychosis and it must be practiced by a skilled individual.

Natural childbirth as a school of thought began in the 1940's with Dick-Read. ${ }^{3}$ In its simplest form, it linked fear, anxiety, and pain. If one was fearless, the labour would be painless. It was stated that "there is no physiologic function in the body which gives rise to pain in the normal course of health." This author finds this view unacceptable. The technique of Lamaze as it is currently practiced is more reasonable. It teaches that pain can be suppressed and dealt with by "positive" conditioned reflexes. The general childbirth education (films, lectures, basic anatomy for the layperson, etc.) is very important in decreasing fear and anxiety. In good classes, the patient also becomes aware of analgesic choices beyond Lamaze to include systemic narcotics and regional analgesia. Given that the Caesarean section rate is $25 \%$ in the United States, for example, it is helpful if these classes include information about anaesthesia as well. I encourage patients to attend these classes, and in an ideal world, an anaesthetist would be involved, perhaps in the delivery suite tour that many classes include.

\section{Systemic analgesia and sedatives}

Systemic narcotics are often the first step beyond less invasive or "natural" techniques. Narcotics can be highly effective for some patients but must be used sparingly with maternal and fetal safety in mind. Maternal side-effects include respiratory depression, nausea, vomiting, slowing of gastrointestinal motility, hypotension, and obtundation of reflexes, ${ }^{1}$ which may lead to aspiration. The newborn may suffer from respiratory depression. While the obstetrician will most often give these drugs before consulting the anaesthetist for regional anaesthesia, narcotics have a place in our armamentarium. Small doses of meperidine, $25-50 \mathrm{mg}$, or fentanyl, $25-50 \mu \mathrm{g}$, iv may be helpful prior

From the Department of Anesthesia, University of California, San Francisco, San Francisco General Hospital. 


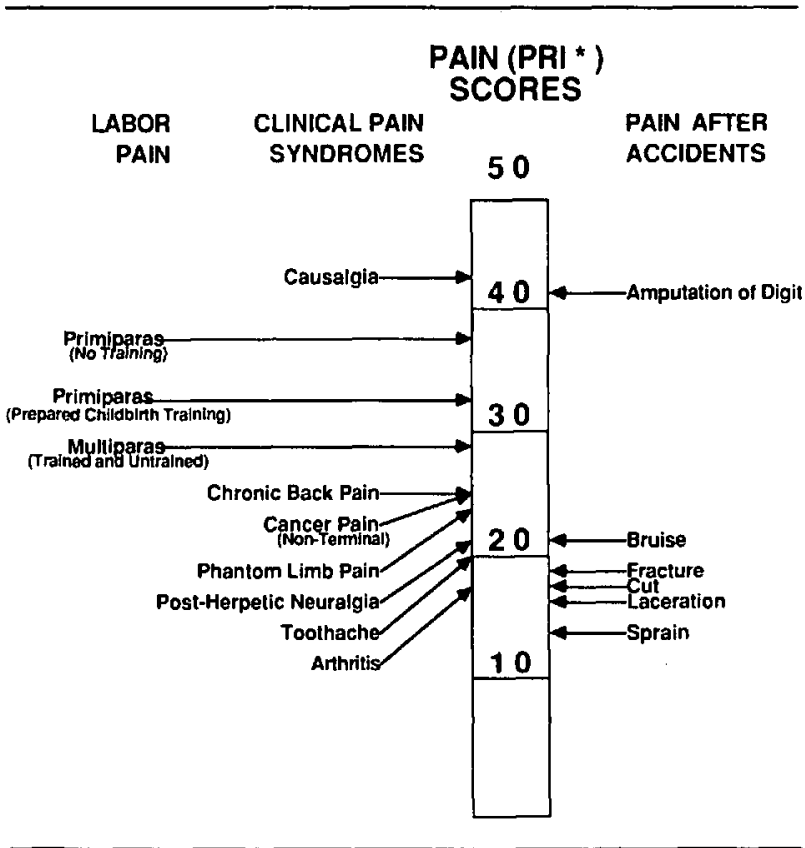

FIGURE 1 Pain scores from the McGill Pain Questionnaire. The pain of patients in labour is compared with other patients' pain in a general pain clinic. (Reprinted with permission from Melzack $R$. The myth of painless childbirth [The John J. Bonica Lecture], Pain 1984; 19: 321-37.)

to placing an epidural catheter if the patient is in extreme pain and difficult to manage. This may also be used to augment regional anaesthesia for Caesarean section if the block is inadequate. Alphaprodine is apparently no longer available but had no unusual benefits. Fentanyl has become very popular and is a drug most anaesthetists are very comfortable using. Morphine is another reasonable choice, 2-3 mg iv or 5-10 $\mathrm{mg} \mathrm{im}$. While butorphanol and nalbuphine are acceptable choices, I have little personal experience with these drugs.

Finally, diazepam has been used widely in obstetrics and is excellent for the highly anxious patient. The drug rapidly crosses the placenta and the newborn may be adversely affected with maternal doses greater than $10 \mathrm{mg}$. When small doses are given to the parturient, $2.5 \mathrm{mg} i \mathrm{v}$, it is very effective. On rare occasions, I use it prior to placing a block or during a Caesarean section in a patient who is extremely anxious. However, in the end, systemic narcotics and anxiolytics have limited use unless small amounts and infrequent dosing are effective. In my view, continuous epidural analgesia is then the appropriate choice.

\section{Regional anaesthesia}

Continuous epidural anaesthesia is the most popular choice for analgesia during labour and delivery. It is highly effective, extremely safe, and very flexible when used

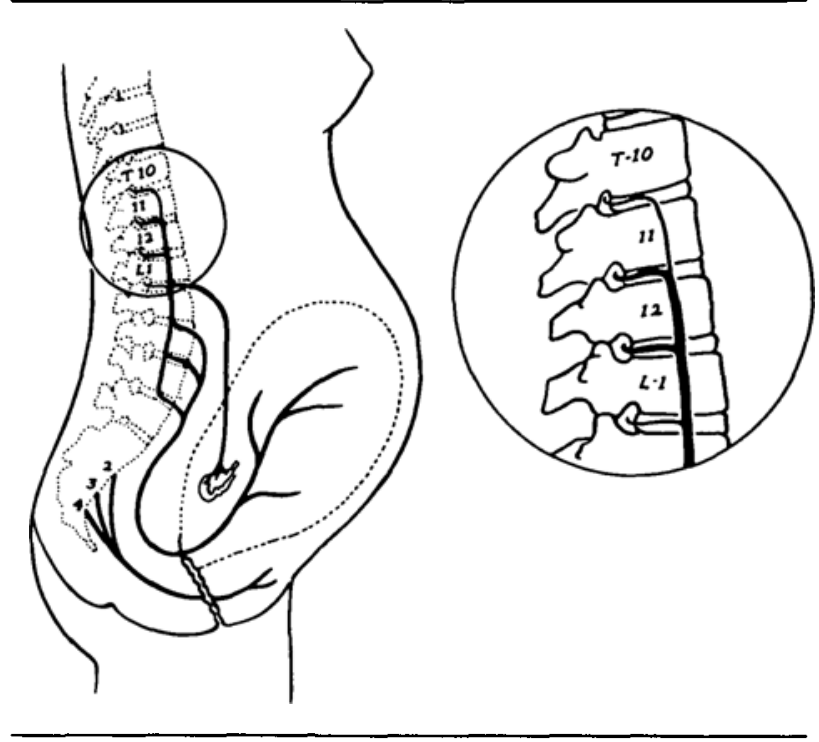

FIGURE 2 Parturition pain pathways. Afferent pain impulses from the cervix and uterus are carried by nerves that accompany sympathetic fibres and enter the neuraxis at $T_{10}, T_{11}, T_{12}$, and $L_{1}$ spinal levels (first stage of labour). Pain pathways from the perineum travel to $S_{2}$, $S_{3}, S_{4}$ via the pudendal nerve (second stage of labour). (Reprinted with permission from Bonica $J J$. The nature of pain of parturition. Clin Obstet Gynaecol 1975: 2: 511.)

correctly. However, regional anaesthesia should only be used by those prepared to treat the possible complications. They must be considered before considering the possible techniques. The most common side-effect is hypotension and it can be expected in the parturient, even when care is taken to avoid it. In a study by this author and colleagues comparing epidural lidocaine $2 \%$ for Caesarean section ${ }^{5}$ with and without epidural fentanyl $1 \mu \mathrm{g} \cdot \mathrm{kg}^{-1}$, we noted approximately $75 \%$ of the patients became hypotensive (systolic BP $<100 \mathrm{mmHg}$ ). All the patients had been prehydrated with $1500 \mathrm{ml}$ of crystalloid solution. While this occurred with Caesarean section patients, it points out that in "good hands," under well-controlled circumstances with reasonable prophylaxis (1500 ml crystalloid), hypotension does and will occur. While it may be less with the lower level of block used for labour, it must be expected, monitored, and treated. More dramatic (and rare) complications include seizure from intravenous injection of local anaesthetics, total spinals, and neurological complications. With this in mind, it is important that the block be performed where equipment for immediate resuscitation is available. This would include: oxygen and positive-pressure breathing equipment, suction, laryngoscope and endotracheal tube as well as appropriate drugs to facilitate tracheal intubation and resuscitation. Automated BP monitoring has added to the safety of this technique. I do not feel that the routine use of ECG monitoring and pulse oximetry is necessary for the patient 
in labour. However, in selected cases (and in the operating room) it is required. Further, the obstetric suite should be furnished with the same level of equipment as the operating room.

Hypotension in the parturient is usually defined as a $25-30 \%$ decrease in systolic blood pressure or a systolic pressure less than $100 \mathrm{mmHg}$. This can initially be treated with position (LUD, Trendelenburg position), and intravenous fluids. If the pressure does not improve within two to three minutes, then ephedrine, 5-15 mg iv, must be given. While small doses of phenylephrine have been suggested by some ${ }^{6} \mathrm{I}$ would not use this routinely. There is a potential for tachyphlaxis to ephedrine, so if the first dose (10-15 mg?) is not immediately successful, I double the dose (20-30 mg). On rare occasions, I have used a 40 $\mathrm{mg}$ bolus to increase the blood pressure adequately. The initial dose of ephedrine in patients with preeclampsia might be reduced to $2.5 \mathrm{mg}$ because of potential sensitivity. The clinician should be more cautious as well with cardiac patients, for example. While ephedrine does cross the placenta ${ }^{7.8}$ it is not harmful when compared to profound hypotension, decreased UBF, fetal hypoxia and acidosis, and potential maternal cardiovascular collapse. Brief hypotension is benign and easily treated but aggressive intervention is mandatory.

\section{Lumbar epidural anaesthesia}

Regional anaesthesia for modern obstetric anaesthesia means lumbar epidural anaesthesia (Figure 3). While caudal anaesthesia is often described in detail, ${ }^{9,10}$ it is very rarely used and potentially unsafe. The double-catheter technique (caudal and epidural) is clearly unreasonable as well. Paracervical blocks fall into a similar category in my view. There is no place for this block if a competent anaesthetist is available. If it is used, extreme caution must be used with the risk of fetal bradycardia carefully considered. Numerous perinatal deaths have been reported with pericervical blocks. Finally, while many obstetricians are fond of pudendal blocks, they are often less than perfect at providing analgesia and may expose the practitioner to HIV and hepatitis. Thus, continuous lumbar epidural analgesia seems best able to provide analgesia with an excellent maternal-fetal safety record.

\section{Contraindications to regional anaesthesia}

Contraindications include (1) patient refusal, (2) infection at the site of needle placement, (3) shock, and (4) bleeding disorders. Some clinicians would exclude patients with specific neurological disease of the spinal cord or patients with potential neurological problems (i.e., diabetes). While any concomitant disease process must be considered carefully, I rarely exclude someone from regional anaesthesia without specific contraindications. The use of

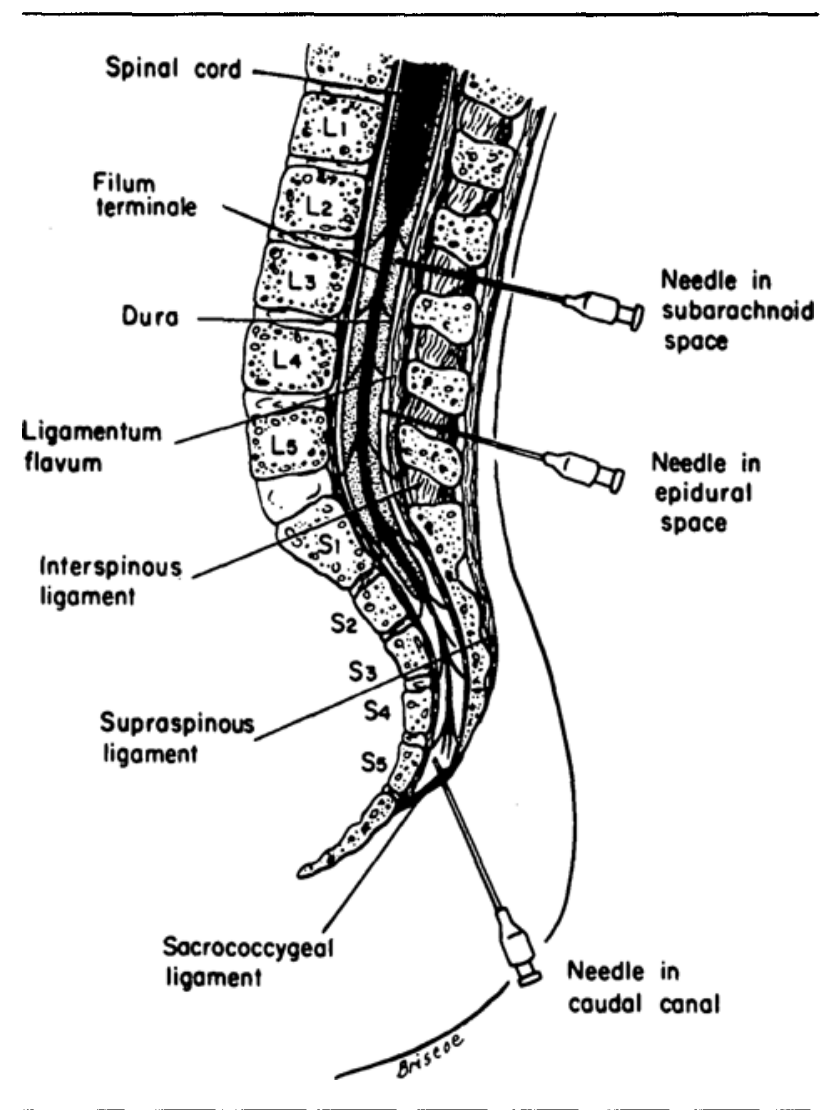

FIGURE 3 Schematic diagram of lumbosacral anatomy showing needle placement for subarachnoid, lumbar epidural, and caudal blocks. While all three approaches to the neuraxis are of interest, the caudal approach seems less useful in today's anaesthetic practice.

aspirin in pregnancy, minidose heparin (with normal partial thromboplastin time) or preeclampsia (with 125,000 platelets, for example) are controversial subjects but again I would only rarely exclude this group. With preeclampsia in mind let me state that there is little sound evidence that a bleeding time is necessary ${ }^{11,12}$ although others would argue this point. ${ }^{13}$

\section{Continuous lumbar epidural for labour and delivery}

The technique is well known and it is presumed that the reader has knowledge of the technical aspects. Several points must be stressed, however. First, prehydration is necessary, through an 18G (or larger) indwelling catheter. I administer $500-1000 \mathrm{ml}$ of crystalloid solution if there are no contraindications such as significant preeclampsia or heart disease. With administration of the higher volume, the incidence of hypotension may be avoided. Prophylactic administration of ephedrine is not recommended. Blood pressure equipment must be in place with emergency equipment immediately available. The level of monitoring should fit the patient. 


\section{Use of a test dose?}

The issue of using a test dose has been widely discussed. ${ }^{14-16}$ Maternal safety must be of paramount concern and the careful administration of all drugs is absolute. The issue in the early 1980s of 2-chloroprocaine's neurotoxicity and bupivacaine's cardiac toxicity made many of us rethink our technique. This issue has led to various "test dose" regimens. One school of thought would insist on adding epinephrine $1: 200,000\left(5 \mu \mathrm{g} \cdot \mathrm{ml}^{-1}\right)$ to lidocaine $1.5 \%$ ( $3 \mathrm{ml}$ or $45 \mathrm{mg}$ lidocaine and thus $15 \mathrm{mg}$ epinephrine). This approach requires the most exacting timing of drug injection and ECG monitoring (in my view) to be successful. The heart rate changes are easy to miss in the patient in labour. Others have suggested the use of air with doppler monitoring ${ }^{17}$ or plain local anaesthetics. ${ }^{18}$ However, I administer plain $1.5 \%$ lidocaine, $5 \mathrm{ml}$ through the needle. I then place the catheter and turn the patient to the opposite side, looking for the changes associated with spinal anaesthesia (loss of motor function, hypotension, or "immediate" pain relief) or intravenous injection (ringing in the ears, "funny" taste in the mouth, etc.). After a threeminute interval, which is usually the time it takes to place the catheter, tape it in position and turn the patient, I then inject another $5 \mathrm{ml}$ plain $1.5 \%$ lidocaine. The monitoring for side-effects is the same. This technique can rule out an intrathecal injection, and if a $T_{8}$ to $T_{10}$ level is achieved, it essentially rules out an intravenous injection or intravenous catheter placement since $5 \mathrm{ml}$ or less of $1.5 \%$ lidocaine rarely achieves this level. This technique avoids the difficulty of trying to count the heart rate of someone, often in severe pain and stressed, with physiological heart rate changes. ${ }^{19}$ It also moves the process forward for the parturient who wants relief quickly. This same approach can be used with $5 \mathrm{ml}$ doses of $0.25 \%$ bupivacaine. Remember that $75 \mathrm{mg}$ of lidocaine or $12.5 \mathrm{mg}$ of bupivacaine may lead to a $T_{2}$ level if it is injected intrathecally. With any test dose, look for the expected response carefully before proceeding with further drug application. If this issue has led to any good, it is chiefly through the use of divided doses of local anaesthetic. Simply put, fractionation of doses is mandatory and large bolus doses of local anaesthetics are unacceptable and sooner or later will lead to a catastrophe.

\section{Choice of agents}

The goal of epidural analgesia is pain relief, but not anaesthesia and this needs to be appreciated by all concerned. Thus, after starting a labour epidural with a fairly concentrated solution (see above) I usually administer $0.125 \%$ plain bupivacaine as a continuous infusion (starting at a rate of $10 \mathrm{ml} \cdot \mathrm{hr}^{-1}$ ). This technique has become extremely popular in recent years, although the concentration of bupivacaine may vary with individual practice. Further, ropivacaine is a probable future possibility. While intermittent top-ups can be used easily enough, the continuous infusion allows for better pain relief (it never wears off completely) and ease for the practitioner. However, monitoring the level of the block, adjustment of the infusion rate (does $10 \mathrm{ml} \cdot \mathrm{hr}^{-1}$ produce too high or low a dermatome level?), and potentially adjusting the local anaesthetic solution are required. Bolus top-ups (bupivacaine, $0.125 \% 5 \mathrm{ml}$ or lidocaine, $1.5 \%, 5 \mathrm{ml}$ for example) may be needed to reestablish a block acutely. Before the infusion rate is increased it should be remembered that the onset of such an adjustment is slow.

\section{Lipid soluble narcotics and local anaesthetics}

This technique has become routine in many centres but should be considered as an alternative, not the routine approach. Current interest centres on continuous epidural infusions during labour of very dilute fentanyl or sufentanil with a dilute local anaesthetic (bupivacaine 0.0625 ?) and epinephrine $(1: 800,000){ }^{20-22}$ Alfentanil has also been looked at in initial studies, but there is little solid information. The combination of intrathecal fentanyl $(25 \mu \mathrm{g})$ and morphine $(0.25 \mathrm{mg})$ has been used with some success during labour and opens up a new area for investigation. ${ }^{23}$ Fentanyl achieves a rapid onset of analgesia while morphine gives greater duration of action. This work is in the early stages, but it is not without risks, ${ }^{24}$ and a more extensive examination is needed. While intrathecal morphine $(0.5-1.0 \mathrm{mg})$ can be highly effective for the first stage of labour, it is not without side-effects, including post-spinal headaches (15\%?), pruritus, nausea, and vomiting. ${ }^{20}$ The addition of fentanyl speeds the onset, but problems remain when considering the intrathecal route. The Sprotte spinal needle and similar products may change the concern related to postdural puncture headaches. Smaller catheters can lead to continuous intrathecal infusions with broad possibilities for pain management but toxicity and neurologic damage must be considered. ${ }^{25}$ Clearly, more investigation is warranted.

When considering epidural sufentanil or fentanyl with local anaesthetics one must return to the basic questions. Is it worthwhile? Does it effect progress in labour, forceps delivery rate, or newborn outcome? Is it "better" than the routine use of local anaesthetics? Many of these questions remain to be answered, but there is a renewed interest in intraspinal narcotics on the labour floor, and widespread use in many centres.

The most typical practice includes an initial dose of fentanyl $(50 \mu \mathrm{g})$ or sufentanil $(10-30 \mu \mathrm{g})$ with the test dose, followed by $1 \mu \mathrm{g} \cdot \mathrm{ml}^{-1}$ of lipid soluble narcotic with a dilute bupivacaine solution, as little as $0.0625 \%$. This is then used as a continuous infusion, typically at 10-14 $\mathrm{ml} \cdot \mathrm{hr}^{-1}$, adjusted to achieve a $\mathrm{T}_{10}$ level. 
This author feels that while this technique has been shown to produce analgesia with less motor effect, it has few other proven benefits and is not without risks. The total dose of narcotic administered must be kept in mind. Some clinicians use as much as $3 \mu \mathrm{g}$ of fentanyl $\cdot \mathrm{ml}^{-1}$ of infusion. At an infusion rate of $15 \mathrm{ml} \cdot \mathrm{hr}^{-1}$, for example, that would equal $45 \mu \mathrm{g} \cdot \mathrm{hr}^{-1}$ which, in a long labour, would be unacceptable and have the potential of high fetal levels of fentanyl being easily reached. Respiratory depression of the newborn has occurred after epidural fentanyl and intrathecal application has the risk of maternal respiratory depression. ${ }^{24}$ Thus, while I use the lowdose combination of fentanyl $\left(1 \mu \mathrm{g} \cdot \mathrm{ml}^{-1}\right)$ and bupivacaine $(0.125 \%)$ as an alternative solution, the total dose of narcotic applied and maternal-fetal risks must be considered.

\section{Spinal analgesia}

Spinal analgesia for labour and delivery was the first regional technique used in obstetrics. In 1900, Dr. Marx used spinal anaesthesia in the United States and noted the ability of cocaine to still "the agonizing and maniacal shrieks of these poor women." Today, this approach is most useful in the second stage or for forceps application, when a saddle block or "low spinal" is often used. The technique is highly effective and easy to perform. The technique is described in standard texts. ${ }^{9}$ Interest in the use of spinal anaesthesia has been revived because of the Sprotte needle ${ }^{26}$ which may reduce the incidence of postdural puncture headache to less than $1 \%{ }^{27,28}$ Also, the various microcatheters, $28 \mathrm{G}$ and $32 \mathrm{G}$ for example, allow for continuous spinal analgesia or anaesthesia. This area has received a serious examination by many investigators in obstetric anaesthesia. However, the reports of neurotoxicity, ${ }^{25}$ apparently related to the local anaesthetic concentration achieved locally, limit this approach. It remains to be seen whether this will be resolved. If it is, spinal anaesthesia would have many of the advantages of continuous lumbar epidural analgesia but with lower total amounts of drugs. The clinician is urged to consider the risks before adopting this technique into routine practice. For selected cases, it may be an excellent choice.

\section{Conclusions}

The practice of obstetric anaesthesia can be highly rewarding. The clinician prepared with an understanding of maternal-fetal physiology (obstetric requirements), systemic narcotics, and regional anaesthesia can be highly effective at relieving pain and bringing about a successful delivery. While alternative techniques should always be considered, particularly those that stress childbirth education, continuous lumbar analgesia remains the most flexible and satisfactory approach. While there is new equipment (fine needles and smaller catheters) on the horizon, it remains to be demonstrated if they can match the success and safety record of present lumbar epidural practice.

\section{References}

1 Melzack R. The myth of painless childbirth (The John J. Bonica Lecture). Pain 1984; 19: 321-7.

2 DeVore J, Hughes S. Psychologic and alternative techniques for obstetric anesthesia. In: Shnider SM, Levinson G (Eds.). Anesthesia for Obstetrics, 2nd ed., Baltimore: Williams \& Wilkins, 1987; 79-88.

3 Dick-Read G. Childbirth Without Fear. 2nd ed. New York: Harper \& Row, 1959.

4 Lamaze F. Painless Childbirth: Psychoprophylactic Method. London: Burke, 1958.

5 Preston P, Rosen $M$, Hughes $S$, et al. Epidural anesthesia with fentanyl and lidocaine for cesarean section: maternal effects and neonatal outcome. Anesthesiology 1988; 68: 938-43.

6 Moran D, Perillo M, Bader A, Datta S. Phenylephrine in treating maternal hypotension secondary to spinal anesthesia. Anesthesiology 1989; 71: A857.

7 Wright R, Shnider SM, Levinson G, Rolbin S, Parer. The effect of maternal administration of ephedrine on fetal heart rate and variability Am J Obstet Gynecol 1981; 57: 734-8.

8 Hughes S, Ward M, Levinson G, et al. Placental transfer of ephedrine does not affect neonatal outcome. Anesthesiology 1985; 63: 217-9.

9 Shnider SM, Levinson G, Ralston D. Regional anesthesia for labor and delivery. In: Shnider SM, Levinson G (Eds.). Anesthesia for Obstetrics, 2nd ed., Baltimore: Williams \& Wilkins, 1987; 109-22.

10 Ostheimer G. Regional anesthesia. In: Ostheimer G (Ed.). Manual of Obstetric Anesthesia, New York: Churchill Livingstone Inc., 1984:165-220.

11 Rogers RPC, Levin J. A critical reappraisal of the bleeding time. Sem Thrombosis Hemostasis 1990; 16: 1-20.

12 Roblin S, Abbott D, Musclow E, Papsin F, Lie L, Freedman $J$. Epidural anesthesia in pregnant patients with low platelet counts. Obstet Gynecol 1988; 71: 918-20.

13 Letsky $E$. Haemostasis and epidural anaesthesia. Int $\mathrm{J}$ Obstet Anesth 1991; 1: 51-4.

14 Biehl $D$. The dilemma of the epidural test dose. Can J Anaesth 1987; 34: 345-8.

15 Cartwright P, McCarroll S, Antzaka C. Maternal heartrate changes with a plain epidural test dose. Anesthesiology 1986; 65: 225-8.

16 Leighton B, Norris M, Sosis M, Epstein R, Chayen B, Larijani $G$. Limitations of epinephrine as a marker of intravascular injection in laboring women. Anesthesiology 1987; 66: 668-91. 
17 Leighton B, Norris M, DeSimone C, Rosko T, Gross

$J$. The air test as a clinically useful indicator of intravenously placed epidural catheters. Anesthesiology 1990; 73: 610-13.

18 Grice S, Eisenach J, Dewan D, Mandell G. Evaluation of 2-chloroprocaine as an effective intravenous test dose for epidural analgesia. Anesthesiology 1987; 67: A627.

19 Chestnut $D$, Owen $C$, Brown $C$, Vandewalker $G$, Weiner $C$. Does labor affect the variability of maternal heart rate during induction of epidural anesthesia? Anesthesiology 1988; 68: 622-5.

20 Hughes $S$. Intraspinal opiates in obstetrics. In: Shnider SM, Levinson G (Eds). Anesthesia for Obstetrics, 2nd ed., Baltimore: Williams \& Wilkins, 1987; 123-41.

21 Chestnut $D$. Continuous infusion epidural analgesia during labor. A randomized double-blind comparison of $0.0625 \%$ bupivacaine, $0.0003 \%$ fentanyl versus $0.125 \%$ bupivacaine. Anesthesiology 1988; 68: 754-9.

22 Phillips $G$. Continuous infusion epidural analgesia in labor. The effect of adding sufentanil to $0.125 \%$ bupivacaine. Anesth Analg 1988; 67: 462-5.

23 Leighton B, DeSimone $C$, Norris $M$, Ben-David B. Intrathecal narcotics for labor revisited: the combination of fentanyl and morphine intrathecally provides rapid onset of profound, prolonged analgesia. Anesth Analg 1989; 69: 122-5.

24 Palmer $C$ : Early respiratory depression following intrathecal fentanyl-morphine combination. Anesthesiology 1991; 74: 1153-5.

25 Rigler $M$, Drasner $K$, Krejcie TC, et al. Cauda equina syndrome after continuous spinal anesthesia. Anesth Analg 1991; 72: 275-81.

26 Sprotte G, Schedle R, Pajunk H, Pajunk $H$. Eine "atraumatische" universalkanüle für einzeitige regionalanaesthesien. Regional Anaesthesia 1987; 10: 104-8.

27 Hughes S. Intraspinal narcotics for analgesia after caesarean section. Current Opinions in Anaesthesiology 1989; 2: 295-302.

28 Cesarini M, Torrielli $R$, Lahaye F, Mene J, Cabiro $C$. Sprotte needle for intrathecal anaesthesia for caesarean section: incidence of postdural puncture headache. Anaesthesia $1990 ; 45: 656-8$. 


\section{Analgésie pour le travail et l'accouchement}

Samuel C. Hughes MD

L'accouchement constitue une expérience très variable en ce qui concerne la douleur et le besoin d'analgésie. Une multipare, par exemple, peut avoir un accouchement vaginal rapide et sans incident, avec peu de besoins d'analgésie, alors que d'autres parturientes ont un besoin important d'analgésie et même d'anesthésie complète. L'anesthésiste doit connaître les voies de transmission de la douleur, les besoins spécifiques liés à la santé, les exigences de la patiente, et une variété d'alternatives pour l'analgésie. L'anesthésiste obstétrical est dans une position unique, puisque beaucoup de ce qu'on lui demande est électif, si l'on pense aux besoins courants d'une salle d'opération. Un autre facteur important est la nécessité d'anticiper et d'être prêt à des changements rapides des besoins et des attentes. L'épidurale de routine pour le travail peut rapidement devenir nécessaire pour l'anesthésie en vue d'une césarienne. Cet aspect d'analgésie et d'anesthésie combinées pour la parturiente est un défi important et en même temps très satisfaisant si l'anesthésiste est bien informé et préparé.

Melzack $^{1}$ dans une conférence intitulée « Le mythe de la douleur de l'enfantement » note qu'une primipare non préparée à l'accouchement présente une douleur similaire à celle de l'amputation d'un doigt et plus importante qu'une douleur de cancer (Figure 1). La préparation à l'accouchement peut diminuer substantiellement la douleur, en diminuant la peur et l'anxiété, et en préparant la patiente à participer à son accouchement. Cependant, il est important que les moniteurs qui donnent des cours de préparation à l' accouchement ainsi que les participants se rappellent qu'il y a de la douleur. La douleur du travail et de l'accouchement provient surtout de récepteurs utérins et périnéaux. La douleur est transmise par les fibres sympathiques aux segments thoraciques $T_{10-12}$ et aux premiers segments lombaires. $\grave{A}$ mesure que le travail progresse, les segments sacrés deviennent de plus en plus impliqués, de telle sorte que pendant le deuxième stage du travail, les racines $S_{2-3-4}$ sont les cibles du soulagement de la douleur (Figure 2). Si la chirurgie abdominale est requise, un niveau d'analgésie à $T_{4}$ ou légèrement plus haut est nécessaire. La connaissance de ces voies de transmission donne au praticien plusieurs alternatives pour l'analgésie.

\section{Techniques alternatives et psychologiques}

Les approches alternatives ont été tentées par beaucoup de patientes et peuvent être judicieuses chez les personnes bien motivées, bien informées, et bien préparées. ${ }^{2} \mathrm{~L}$ 'hypnose a eu un certain succès mais les patientes doivent $y$ être sensibles et bien préparées. Cette préparation comprend plusieurs séances de conditionnement avec un thérapeute. Les effets indésirables comprennent cependant l'anxiété aiguë et la psychose, et l'hypnose doit être pratiquée par un thérapeute habile.

L'école de l'accouchement naturel a débuté probablement vers 1940 avec Dick-Read. ${ }^{3}$ Dans sa forme la plus simple, cette école établit un lien entre la peur, l'anxiété et la douleur. Chez une personne sans peur, le travail devrait être sans douleur. On a établi «qu'il n'y a pas de fonction physiologique dans le corps qui donne naissance à la douleur dans le cours normal d'un état de santé $»$. Cet auteur trouve cette vision inacceptable. La technique de Lamaze ${ }^{4}$ pratiquée actuellement est plus raisonnable. Elle enseigne que la douleur peut être supprimée et contrôlée par des réflexes conditionnés « positifs ». L'éducation générale à la naissance (films, cours, anatomie de base pour les non initiés, etc.) diminue de façon importante la peur et l'anxiété. Dans les bonnes classes, les patientes deviennent averties des choix d'analgésie au delà de la méthode de Lamaze: on y parle de narcotiques systémiques et d'anesthésie régionale. Considérant que le taux de césariennes aux États-Unis est de 25\%, par exemple, il devient utile que ces cours comprennent aussi de l'information à propos de l'anesthésie. J'encourage les patientes à participer à ces cours, et dans un monde idéal, un anesthésiste devrait être impliqué, probablement dans la tournée des salles d'accouchement prévu dans ces cours.

\section{Analgésie systémique et sédatifs}

Les narcotiques systémiques sont souvent la première étape d'analgésie au-delà des techniques moins invasives ou « naturelles ». Les narcotiques sont très efficaces chez certaines patientes mais doivent être utilisés de façon conservatrice en gardant à l'esprit la sécurité de la mère et de l'enfant. Les effets secondaires maternels comprennent la dépression respiratoire, les nausées, les vomissements, le ralentissement de la motilité gastro-intestinale, l'hypotension et la diminution des réflexes ${ }^{1}$ qui peut conduire à 


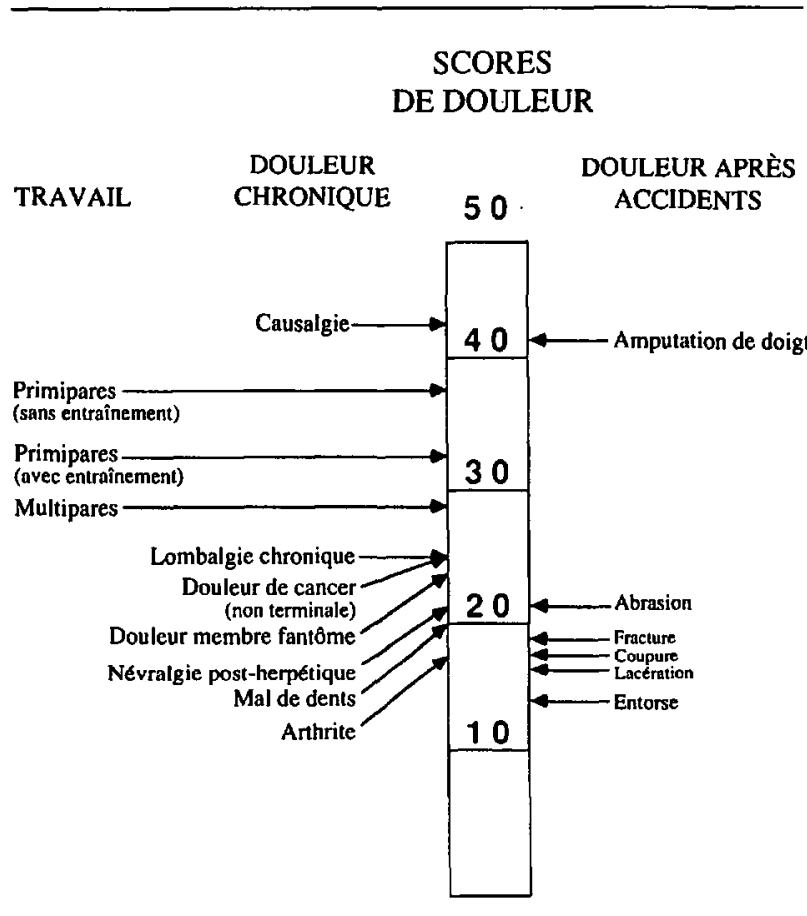

FIGURE 1 Scores de douleur (Questionnaire de McGill). La douleur des patientes en travail est comparée à celle d'autres patients d'une clinique de douleur (Reproduit de Melzack $R$. The myths of painless childbirth [The John J. Bonica Lecture], Pain $1984 ; 19$ : 321-37. Avec permission).

l'aspiration. Le nouveau-né peut souffrir de dépression respiratoire. Même si l'obstétricien va donner habituellement ces substances avant de consulter l'anesthésiste pour une anesthésie régionale, les narcotiques ont une place dans notre panoplie. De petites doses de mépéridine, $25-50 \mathrm{mg}$, ou de fentanyl, $25-50 \mu \mathrm{g}$, par voie intraveineuse seront utiles avant de placer un cathéter épidural si la patiente est très agitée ou présente une douleur extrême. Ce mode d'analgésie peut aussi être utilisé pour améliorer l'anesthésie régionale pour la césarienne si le bloc est incomplet. L'alphaprodine n'est plus disponible semble-t-il, mais n'avait pas de bénéfices particuliers. Le fentanyl est devenu très populaire et est une substance très familière aux anesthésistes. La morphine est un autre choix raisonnable, à raison de 2 à $3 \mathrm{mg} i v$ ou 5 à $10 \mathrm{mg}$ im. Le butorphanol et la nalbuphine sont des choix acceptables, mais j'ai peu d'expérience personnelle avec ces substances.

Enfin, le diazépam a été très largement utilisé en obstétrique et demeure excellent pour une patiente très anxieuse. Cette substance traverse rapidement le placenta, et le nouveau-né peut subir des effets indésirables avec des doses maternelles supérieures à $10 \mathrm{mg}$. Lorsque de petites doses sont données aux parturientes, à raison de $2,5 \mathrm{mg} i \mathrm{v}$, elles sont très efficaces. Dans de rares occasions, je

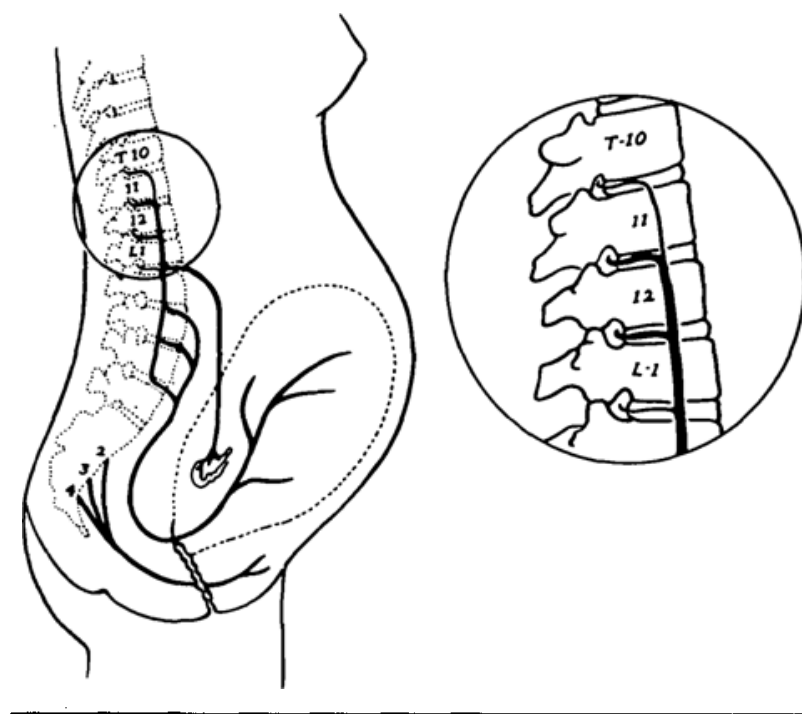

FIGURE 2 Voies de la douleur du travail. Les influx afférents du col et de l'utérus sont transmis par des nerfs qui accompagnent les fibres sympathiques et joignent la moëlle à $\mathrm{T}_{10}, \mathrm{~T}_{11}, \mathrm{~T}_{12}$ et $\mathrm{L}_{1}$ (premier stade). La douleur du périnée est transmise aux racines $S_{2}, S_{3}, S_{4}$ via le nerf honteux (deuxième stade du travail). (Reproduit de Bonica J.J. The nature of pain of parturition. Clin Obst Gynaecol 1975;2:511. Avec permission).

l'utilise avant de faire une épidurale ou pendant une Césarienne chez des patientes très anxieuses. Cependant, finalement, les narcotiques et anxiolytiques systémiques ont des indications limitées à moins que l'on utilise des doses faibles et occasionnelles. À mon sens, l'analgésie épidurale continue représente le meilleur choix.

\section{Anesthésie régionale}

L'anesthésie épidurale continue est le choix le plus populaire pour l'analgésie pendant le travail et l'accouchement. Elle est très efficace, sécuritaire, et très flexible lorsqu'employée correctement. Cependant, l'anesthésie régionale devrait être l'apanage de ceux préparés à traiter les complications possibles. Il faut penser à ces dernières avant d'envisager les techniques possibles. L'effet secondaire le plus courant est l'hypotension et doit être prévu chez la parturiente, même si l'on prend soin de l'éviter. Dans une étude par cet auteur et ses collègues qui ont comparé la lidocaïne $2 \%$ en épidurale pour la Césarienne avec ou sans fentanyl épidural $1 \mu \mathrm{g} \cdot \mathrm{kg}^{-1}$, nous avons noté qu'environ $75 \%$ des patientes devenaient hypotendues (pression artérielle systolique $<100 \mathrm{mmHg}$ ). Toutes les patientes avaient été préhydratées avec $1,5 \mathrm{ml}$ de solution cristalloïde. Même si cette hypotension s'est produite chez des patientes soumises à une césarienne, l'étude note que même entre bonnes mains, dans des circonstances bien contrôlées et une prophylaxie liquidienne raisonnable l'hypotension apparaît et va apparaître. Même si elle peut 
être moins importante avec le niveau inférieur utilisé pour le travail, elle doit être attendue, surveillée et traitée. Les complications plus rares et le plus dramatiques comprennent les convulsions consécutives à l'injection intraveineuse d'anesthésiques locaux, les anesthésies rachidiennes totales, et les complications neurologiques. Ces faits nous rappellent qu'il est important de faire ces blocs dans un endroit où un équipement de réanimation immédiate est disponible. Il peut comprendre : de l'oxygène et du matériel de ventilation à pression positive, une succion, un laryngoscope et un tube endotrachéal ainsi que les agents nécessaires pour faciliter l'intubation endotrachéale et la réanimation. La mesure automatique de la pression artérielle a amélioré la sécurité de la technique. Je ne crois pas personnellement que l'usage de routine de l'ECG et de l'oxymétrie soient nécessaires chez les patientes en travail. Cependant, dans une telle situation (et dans la salle d'opération) ils deviennent nécessaires. De plus, la salle d'accouchement doit avoir le même équipement que la salle d'opération.

L'hypotension chez la parturiente se définit comme une baisse de 25 à $30 \%$ de la pression artérielle systolique ou une pression systolique inférieure à $100 \mathrm{mmHg}$. Le traitement initial consistera en un changement de position (déplacement de l'utérus à gauche, Trendelenburg), et en liquide intra-veineux. Si la pression ne s'améliore pas dans les deux à trois premières minutes, on administrera alors de l'éphédrine, à raison de 5 à $15 \mathrm{mg}$ iv. Même si l'on a suggéré l'utilisation de phényléphrine à petites doses ${ }^{6}$ je n'en recommande pas l'utilisation de routine. L'éphédrine à un potentiel de tachyphylaxie, de telle sorte que si la première dose (10 à $15 \mathrm{mg}$ ) ne donne pas de résultats immédiats, je double la dose (20 à $30 \mathrm{mg}$ ). En de rares occasions, j'ai administré un bolus de $40 \mathrm{mg}$ pour corriger adéquatement la pression artérielle. La dose initiale d'éphédrine chez les patientes avec pré-éclampsie peut être réduite à $2,5 \mathrm{mg}$ à cause d'une hypersensibilité possible. Le clinicien sera aussi plus prudent avec les patientes cardiaques, par exemple. Même si l'éphédrine traverse le placenta, ${ }^{7,8}$ elle ne présente pas de danger si on la compare à l'hypotension profonde, à la diminution du débit sanguin utérin, à l'hypoxie et l'acidose foetale, et à un collapsus cardio-vasculaire maternel possible. L'hypotension de courte durée a peu d'effets et se corrige facilement avec une intervention agressive.

\section{Anesthésie épidurale lombaire}

L'anesthésie régionale en pratique obstétricale moderne signifie anesthésie épidurale lombaire (Figure 3). Même si l'anesthésie caudale est souvent décrite en détail, ${ }^{9,10}$ elle est rarement utilisée et possiblement non sécuritaire. La technique à double cathéter (caudal et épidural) est tout aussi déraisonnable. Les blocs paracervicaux tombent à

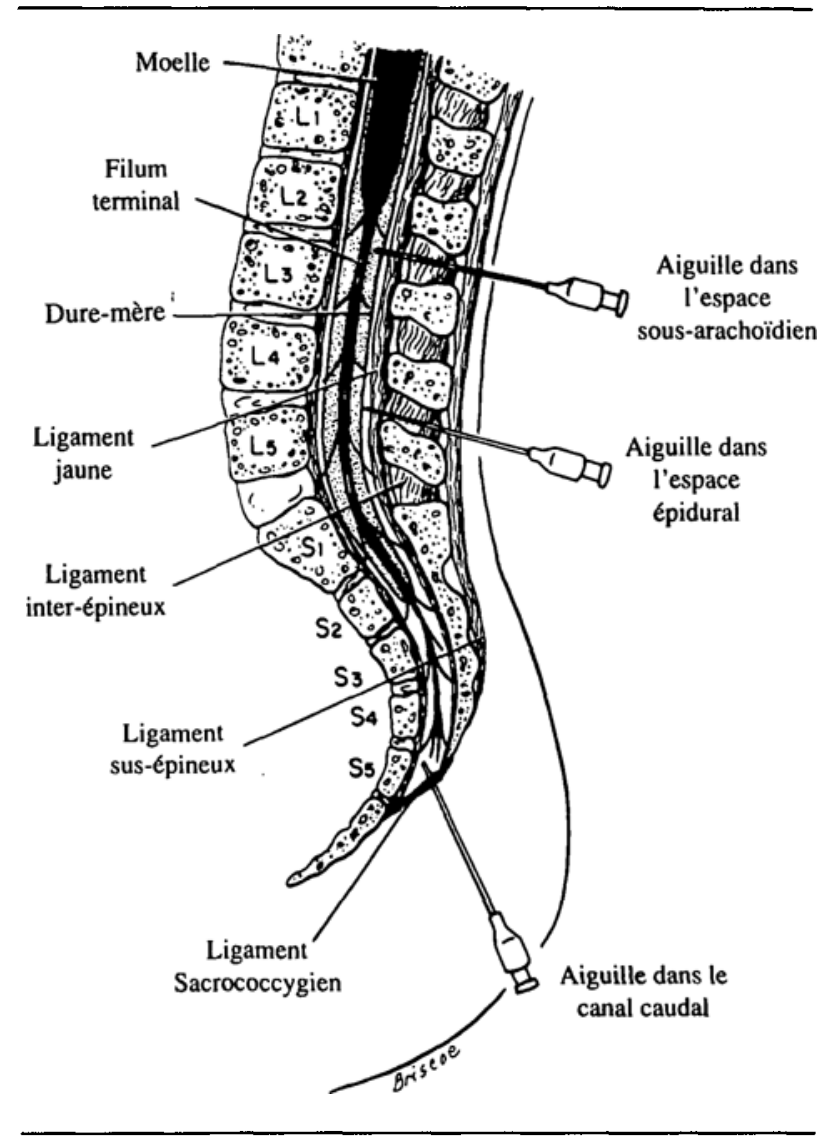

FIGURE 3 Diagramme de l'anatomie lombosacrée montrant la position de l'aiguille pour les blocs sous-arachnoïdien, épidural lombaire et caudal. Même si les trois approches sont intéressantes, l'approche caudale semble moins utile dans la pratique actuelle.

mon sens dans la même catégorie. Il n'y a pas de place pour ces blocs si un anesthésiste compétent est disponible. Si on les utilise, il faut être extrêmement prudent à cause du risque de bradycardie foetale. De nombreux décès périnataux sont mentionnés à la suite de blocs para-cervicaux. Finalement, même si plusieurs obstétriciens chérissent les blocs honteux, ils donnent souvent une analgésie inférieure et peuvent exposer le praticien au virus HIV et à l'hépatite. Dès lors, l'anesthésie épidurale continue par voie lombaire semble procurer la meilleure analgésie avec un excellent dossier de sécurité foeto-maternelle.

\section{Contre-indications à l'anesthésie régionale}

Les contre-indications comprennent: 1) refus de la patiente, 2) infection au site d'insertion de l'aiguille, 3) choc, et 4) trouble de la coagulation. Certains praticiens voudraient exclure les patientes avec maladie neurologique médullaire spécifique ou les patientes avec des problèmes neurologiques potentiels (diabète par exemple). Même si l'on doit tenir compte attentivement des maladies associées, je prive rarement une personne de l'anesthésie 
régionale, hors des contre-indications spécifiques. Il y a des controverses sur l'utilisation de l'aspirine pendant la grossesse, celle de l'héparine en mini-dose (avec temps de thromboplastine partiel normal) ou la pré-éclampsie (avec 125000 plaquettes par exemple): je répète que je prive rarement ces patientes de l'analgésie. Quant on pense à la pré-éclampsie je considère qu'il y a peu d'évidences solides pour nécessiter un temps de saignement ${ }^{11,12}$ même si d'autres personnes peuvent être en désaccord. ${ }^{13}$

\section{Épidurale continue lombaire pour le travail et l'accouchement}

Cette technique est bien connue et j'assume que le lecteur en connaît les aspects techniques. Il faut quand même insister sur quelques points cependant. D'abord il faut préhydrater avec un cathéter de calibre 18 (ou plus grand). J'administre 500-1 $000 \mathrm{ml}$ de solution cristalloüde s'il n'y a pas de contre-indications telles la pré-éclampsie ou une maladie cardiaque. L'administration d'un volume plus important diminue l'incidence d'hypotension. Je ne recommande pas l'administration prophylactique d'éphédrine. L'appareil de mesure de la pression artérielle doit être en place et l'équipement d'urgence disponible immédiatement. Le niveau de surveillance devrait être approprié pour la situation clinique de la patiente.

\section{Doit-on utiliser une dose-test ?}

Cette question a été largement débattue. ${ }^{14-16}$ La sécurité de la mère doit être prioritaire et le soin porté à l'administration des agents est très important. Le problème de la neurotoxicité de la 2-chloroprocaïne pendant le début des années 80 et la toxicité cardiaque de la bupivacaïne nous ont fait reviser notre technique. Ces problèmes ont conduit à différents protocoles de doses-tests. Une école de pensée insiste sur l'addition de $5 \mu \mathrm{g} \cdot \mathrm{ml}^{-1}$ d'adrénaline $1 / 200000$ à $3 \mathrm{ml}$ de lidocaïne $1,5 \%$ (45 mg de lidocaïne et donc 15 $\mu \mathrm{g}$ d'adrénaline). Cette approche exige un synchronisme parfait de l'injection et de la surveillance à l'électrocardiogramme pour être utile (dans mon esprit). Les variations de fréquence cardiaque sont faciles à manquer chez la patiente en travail. D'autres suggèrent l'injection d'air avec auscultation au doppler, ${ }^{17}$ ou d'anesthésiques locaux seuls. ${ }^{18}$ De toutes façons j' injecte $5 \mathrm{ml}$ de lidocaïne $1,5 \%$ par l'aiguille. Je place ensuite le cathéter et tourne la patiente sur l'autre côté, en recherchant les changements associés à l'anesthésie rachidienne (perte de motricité, hypotension, ou soulagement immédiat) ou d'injection intra-veineuse (tinnitus, goût métallique dans la bouche, etc.). Après trois minutes d'attente, qui représentent le temps nécessaire pour poser le cathéter, le fixer et retourner la patiente, j'injecte alors un autre $5 \mathrm{ml}$ de lidocaïne à $1,5 \%$ sans additif. La recherche des effets secondaires se fait de la même façon. Cette technique élimine à toutes fins pratiques une injection intrathécale, et si on l'on obtient un niveau de $T_{8}$ à $T_{10}$, ceci élimine une injection intra-veineuse ou un positionnement intraveineux du cathéter puisque $5 \mathrm{ml}$ ou moins de lidocaïne $1,5 \%$ vont rarement atteindre ce niveau. Cette technique évite la difficulté de compter la fréquence cardiaque chez une personne, souvent en douleur sévère et stressée, et qui présente pour ces raisons des changements physiologiques de fréquence cardiaque. ${ }^{19}$ Cette approche accélère l'apparition d'analgésie chez la parturiente qui désire un soulagement rapide. Elle peut être aussi employée avec des doses de $5 \mathrm{ml}$ de bupivacaïne à $0,25 \%$. Il faut se rappeler que $75 \mathrm{ml}$ de lidocaïne ou $12,5 \mathrm{mg}$ de bupivacaïne amèneront à un niveau d'analgésie à $T_{2}$ si l'injection est intrathécale. Quelle que soit la technique de dose-test utilisée, il faut rechercher la réponse attendue soigneusement avant d'injecter' des quantités supplémentaires d'agent anesthésique. Cette question a confirmé le bénéfice de la division des doses d'anesthésiques locaux. Considéré simplement, le fractionnement des doses est obligatoire et des bolus importants d'anesthésiques locaux sont inacceptables, et tôt ou tard conduiront à la catastrophe.

\section{Choix des agents}

Le but de l'analgésie épidurale est le soulagement de la douleur, et non pas l'anesthésie; il faut s'en rappeler. Ainsi, une fois que l'épidurale pour le travail a démarré avec des concentrations initiales relativement élevées (voir ci-haut) j'administre habituellement de la bupivacaïne à $0,25 \%$ en infusion continue (taux initial de $10 \mathrm{ml} \cdot \mathrm{hre}^{-1}$ ). Cette technique est devenue populaire récemment, même si la concentration de bupivacainne peut varier d'un endroit à l'autre. De plus, la ropivacaïne représente une possibilité du futur. Même si les réinjections sont faciles à employer, l'infusion continue assure une meilleure analgésie (elle ne disparaît jamais complètement) et facilite la tâche du praticien. Cependant, il faut surveiller le niveau du bloc, ajuster le taux d'infusion (est-ce que $10 \mathrm{ml} \cdot \mathrm{hre}^{-1}$ produisent un bloc trop haut ou insuffisant ?), et possiblement ajuster la solution d'anesthésique local. Les réinjections (la bupivacaïne, $0,125 \% 5 \mathrm{ml}$, ou lidocaïne, $1,25 \%, 5 \mathrm{ml}$ ) peuvent devenir nécessaires pour rétablir un bloc, et l'effet d'un tel ajustement est lent.

\section{Narcotiques liposolubles et anesthésiques locaux}

Cette technique est établie de routine dans plusieurs centres mais devrait être considérée comme une alternative et non pas une approche de routine. L'attention se porte actuellement sur les infusions épidurales continues, pendant le travail, de solutions très diluées de fentanyl ou de sufentanil ajoutées à une solution diluée d'anesthésique local (bupivacaïne 0,0625) et d'adrénaline (1: 
$800000) .{ }^{20-22}$ On a aussi évalué l'alfentanil dans quelques travaux, mais il y a peu d'informations utiles. La combinaison de fentanyl $(25 \mu \mathrm{g})$ et de morphine $(0,25 \mathrm{mg})$ intrathécal a connu un certain succès pendant le travail et ouvre ainsi un nouveau champ d'évaluation. ${ }^{23}$ Le fentanyl procure un début d'analgésie rapide alors que la morphine amène une plus grande durée d'action. Ce travail est a ses débuts mais il n'est pas sans risques ${ }^{24}$ et il faut pousser plus loin l'évaluation. Même si la morphine intrathécale $(0,25-1 \mathrm{mg})$ peut être très efficace dans le premier stade du travail, elle n'est pas sans effets secondaires : céphalées rachidiennes (15\%?), prurit, nausées et vomissements. ${ }^{20}$ L'addition de fentanyl accélère le début d'action, mais la voie intrathécale soulève certains problèmes. L'aiguille de Sprotte et d'autres outils similaires peuvent diminuer l'inquiétude soulevée par les céphalées rachidiennes. De plus petits cathéters peuvent faciliter les infusions intrachécales continues avec des possibilités importantes pour l'analgésie, mais la toxicité et les dommages neurologiques doivent être pris en considération. ${ }^{25}$ Il faut certainement beaucoup plus de travaux d'évaluation.

Lorsque l'on considère l'addition de sufentanil ou fentanyl épidural à un anesthésique local, nous devons retourner aux questions principales. Est-ce que cela en vaut la peine? Est-ce que la combinaison modifie le progrès du travail, le taux d'utilisation des forceps, ou le sort du nouveau-né? Est-ce que la combinaison est meilleure que l'utilisation routinière d'anesthésiques locaux? Beaucoup de ces questions demandent des réponses, mais il y a un intérêt accru pour l'utilisation des narcotiques sous-arachnoïdiens dans les unités de travail, et l'usage est courant dans certains centres.

La pratique la plus courante comprend une dose initiale de fentanyl $(50 \mu \mathrm{g})$ ou de sufentanil $(10-30 \mu \mathrm{g})$ injectée avec la dose-test, suivie d'une solution comprenant 1 $\mu \mathrm{g} \cdot \mathrm{ml}^{-1}$ de narcotique liposoluble et une solution diluée de bupivacaïne, aussi faible que $0,0625 \%$. Ce mélange est administré en infusion continue, habituellement à 10-14 $\mathrm{ml} \cdot \mathrm{hre}^{-1}$, avec ajustement pour maintenir un niveau d'analgésie à $T_{10}$.

Cet auteur considère que même si cette technique produit de l'analgésie avec moins d'effets moteurs, elle a peu d'autres bénéfices prouvés et n'est pas sans risques. La dose totale de narcotique administrée doit être notée. Quelques cliniciens utilisent jusqu'à $3 \mu \mathrm{g}$ de fentanyl $\cdot \mathrm{ml}^{-1}$ de solution. $\grave{A}$ un taux d'infusion de 15 $\mathrm{ml} \cdot \mathrm{hre}^{-1}$, par exemple, ceci équivaudrait à $45 \mu \mathrm{g} \cdot \mathrm{hre}^{-1}$ pendant un long travail, ce qui serait inacceptable à cause d'une atteinte potentielle due au haut niveau sérique de fentanyl chez le foetus. On a déjà noté de la dépression respiratoire chez le nouveau-né après fentanyl épidural et l'injection intrathécale augmente le risque de dépression respiratoire chez la mère. ${ }^{24}$ Dès lors, même si j'utilise une combinaison à faible dose de fentanyl $(1 \mu \mathrm{g} \cdot \mathrm{ml})$ et de bupivacaïne $(0,125 \%)$ comme alternative, la dose totale de narcotique administrée et les risques pour la mère et le foetus doivent être pris en considération.

\section{Analgésie intra-rachidienne}

L'analgésie sous-arachnoïdienne pour le travail et l'accouchement a été la première technique d'anesthésie régionale employée en obstétrique. En 1900, le docteur Marx a employé l'anesthésie sous-arachnoïdienne aux États-Unis et a constaté la capacité de la cocaine à faire disparaître "le cris d'agonie de ces pauvres femmes". Aujourd'hui cette approche est surtout utile dans le second stade ou lors de l'application de forceps, quand un bloc spinal bas est utilisé. La technique est très efficace et facile à faire. Cette technique est décrite dans les monographies courantes. ${ }^{9}$ L'anesthésie rachidienne présente un nouvel intérêt à cause de l'aiguille de Sprotte ${ }^{26}$ qui peut diminuer l'incidence de céphalée rachidienne à moins de $1 \% .^{27,28} \mathrm{De}$ plus, les nombreux micro-cathéters, de calibres 28 et 30 par exemple, permettent l'administration d'analgésie ou d'anesthésie intra-rachidienne continue. Ce champ d'utilisation a été sérieusement évalué par de nombreux investigateurs en anesthésie obstétricale. Cependant, certains cas rapportés de neurotoxicité, ${ }^{25}$ apparemment associés à la concentration d'anesthésique local obtenue au site d'injection, limitent cette approche. Il reste à voir si cette question sera résolue. Si elle l'est, l'anesthésie sous-arachnoïdienne aurait plusieurs des avantages de l'analgésie épidurale lombaire continue mais avec une quantité totale d'agents plus faible. Le clinicien doit cependant évaluer les risques avant d'adopter cette technique en pratique courante. Elle peut être un excellent choix dans certaines situations.

\section{Conclusion}

La pratique de l'anesthésie obstétricale peut être très encourageante. Le clinicien bien préparé avec une compréhension de la physiologie foeto-maternelle, des narcotiques systémiques, et de l'anesthésie régionale sera très habile à soulager la douleur et à amener un accouchement réussi. Même si des approches alternatives devraient toujours être prises en considération, particulièrement celles qui insistent sur l'éducation à la naissance, l'analgésie lombaire continue demeure l'approche la plus flexible et la plus satisfaisante. Même s'il y a de l'équipement nouveau (aiguilles fines et petits cathéters) à l'horizon, il faut d'abord démontrer qu'il a le même taux de succès et de sécurité que l'analgésie épidurale lombaire telle que pratiquée actuellement.

\section{Références \\ (Voir page R22)}

